Open Access

\title{
Spain: from massive immigration to vast emigration?
}

\author{
Mario Izquierdo, Juan F. Jimeno and Aitor Lacuesta*
}

\author{
*Correspondence: aitor.lacuesta@ \\ bde.es \\ Banco de España, Madrid, Spain
}

\begin{abstract}
Large immigration flows during the 1995-2007 period increased the weight of foreigners living in Spain to $12 \%$ of the total population. The rapid increase in unemployment associated with the Great Recession and the subsequent European debt crisis, substantially changed migration flows, so that, from the beginning of the 2010s, Spain experienced positive net outflows. In this paper, we take on three tasks. First, we show that sensitivity of migration flows to unemployment is similar between Spaniards born in Spain and foreigners that entered in Spain during the last 20 years. Second, we estimate the importance of past network effects of foreigners and the recent network effects of Spaniards in shaping these migration flows. Finally, we will use these estimations to conjecture that the rapid creation of networks of Spaniards abroad might keep their emigration rates growing, thus counterbalancing the effects of outflows due to the recent fall in the unemployment rate.

JEL classification: F22, J64, J61

Keywords: Migration inflows and outflows, Unemployment, Networks
\end{abstract}

\section{Introduction}

Just before the Great Recession, Spain received massive migration inflows that contributed to an average annual population growth of $1.4 \%$ between 2000 and 2007 and increased the weight of the foreign population from 2 to $12 \%$. However, the effects of the Great Recession on the Spanish labor market were remarkable: From peak (third quarter of 2007) to trough (first quarter of 2014), employment fell by $18.3 \%$, while the unemployment rate reached a maximum of 26.9 \% (first quarter of 2013). Not surprisingly, migration inflows and outflows changed significantly since 2010 . The questions that we address in this paper are twofold. First, we estimate to what extent changes in migration flows of foreigners and nationals responded differently to the worsening in the labor market situation. Second, we discuss whether the changes in migration flows should be expected to persist and, therefore, whether Spain could be in transition from massive immigration of foreigners to vast emigration of Spaniards.

To answer these questions, we carefully look at the behavior of migration inflows and outflows of different population groups. Indeed, it is interesting to see that during the crisis, while foreigners experienced emigration rates above $6 \%$, only $0.1 \%$ of Spaniards born in Spain moved abroad. Either migration flows of Spaniards were less sensitive to unemployment than those of foreigners or the former faced larger

(c) 2016 Izquierdo et al. Open Access This article is distributed under the terms of the Creative Commons Attribution 4.0 International License (http://creativecommons.org/licenses/by/4.0/), which permits unrestricted use, distribution, and reproduction in any medium, provided you give appropriate credit to the original author(s) and the source, provide a link to the Creative Commons license, and indicate if changes were made. 
emigration costs due for instance to a lack of networks abroad. The underlying motivation is important since each explanation has different long-term consequences on migration flows. If Spaniards migration flows are not very sensitive to changes in unemployment developments, something that was confirmed in the case of internal migration in Spain (Antolín and Bover 1997; Bentolila and Dolado 1991), migration outflows abroad might not acquire the sufficient entity to generate any relevant network effects that could lower migration costs. Hence, under this scenario, large migration outflows would be unlikely. On the contrary, if migration flows abroad were sensitive to changes in unemployment and networks effects started to play some role, these outflows would continue growing, even if some improvement in the labor market situation in Spain took place. There are two reasons why we do not neglect this possibility upfront. One is the rapid creation of networks observed in Spain during the arrival of large inflows in the expansionary period just before the crisis. Another is the Spanish experience of large migration outflows abroad during the period 1950-1970, which reached a maximum of $0.7 \%$ of population (Fig. 1) even at a time when GDP per capita was growing above $5 \%$ per year (Prados de la Escosura 1993).

In short, in this paper, we take on three tasks. First, we try to disentangle whether the sensitivity of migration flows with respect to unemployment is different between Spaniards and foreigners residing in Spain. Second, we estimate the importance of past network effects of foreigners and the recent network effects of Spaniards in shaping these migration flows. Finally, we will use these estimations to hypothesize about future migration outflow scenarios. The structure of the paper closely resembles these three goals. First, we describe the data sources used to measure migration inflows and outflows. We then focus on the migration inflows of foreign nationals, and on the outflows of Spaniards born in Spain, to estimate their responses to economic conditions, considering also their sociodemographic composition. Finally, we estimate the emigration costs and conclude with some comments on the implications of these migration flows for future potential growth.

\section{Data}

\subsection{Sources}

Data on gross migration flows in Spain are quite limited in terms of both details and time span. Until recently, data on migration outflows came exclusively from records of passengers leaving the country by sea or air and from information on official bilateral programs of organized migration to Europe. This is why most of the studies on Spanish emigration had to rely on destination country information. ${ }^{1}$ It was not until 1998 that an organized attempt was made to keep records of migration inflows and outflows based on municipal registers, which yielded the migration module of the Estadistica de Variaciones Residenciales, available since 2002. However, this statistical source has some drawbacks, because although foreign nationals arriving in Spain have an incentive to enroll on the municipal register, they do not provide information needed to update it when they leave the country. To correct this, since 2006, foreign nationals (from non-EU countries and those who do not have a permanent residence permit) are required to renew their registration every 2 years; those who fail to do so are considered to have left the country and are dropped from the register. Since 2009, the National 


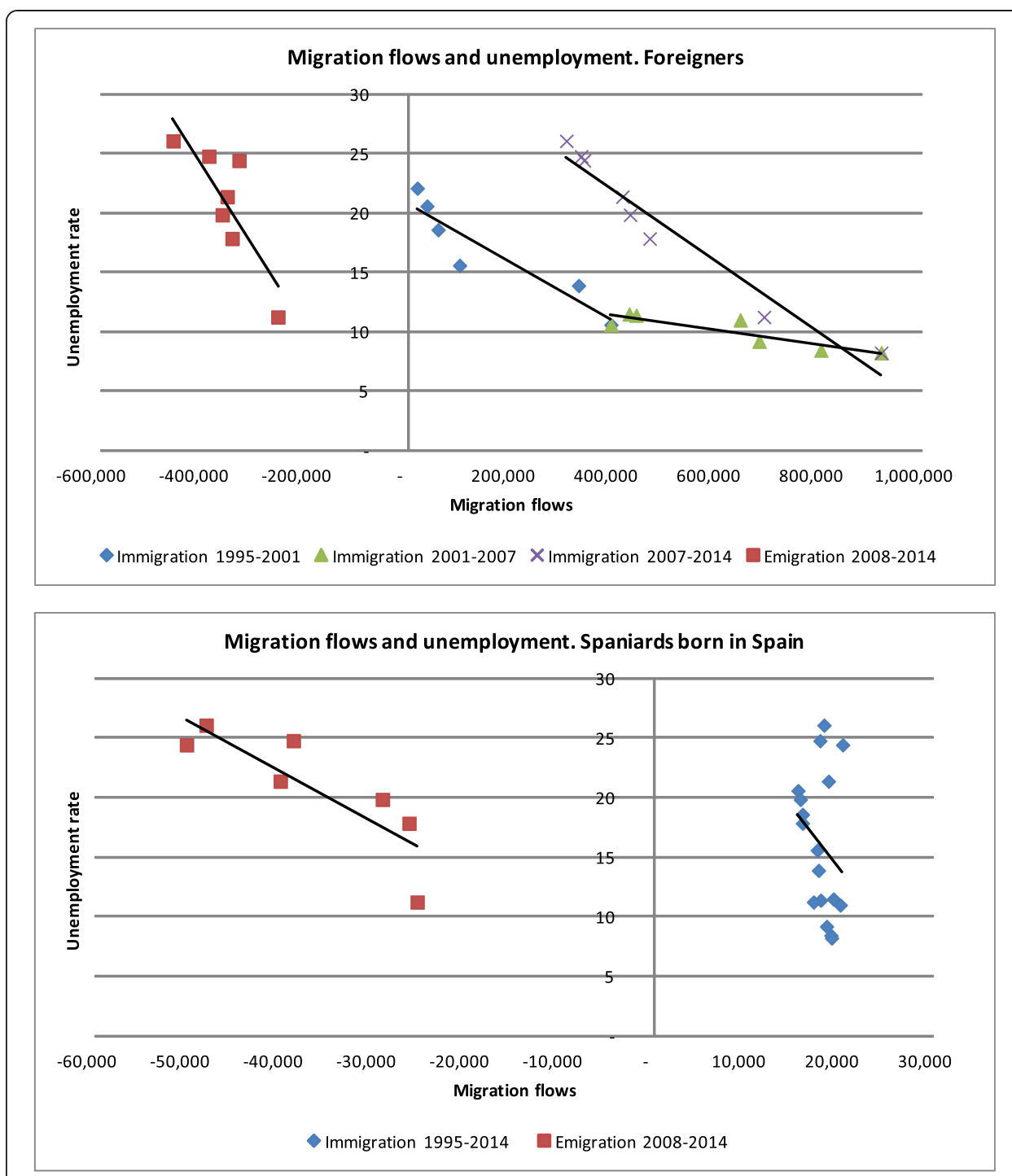

Fig. 1 Migration flows to and from Spain as a function of unemployment rate

Statistics Office (INE) also uses alternative surveys to obtain information on exits of EU citizens and migrants with permanent residence permits in order to assign an estimated departure date to those exits. This information is the basis for the data on outflows at the Estadística de Migraciones provided by the INE since 2008.

As for migration inflows and outflows of Spanish nationals, they are better captured by the municipal registers. However, the information on outflows is not free of problems, since it relies on enrolments on Spanish consulates and embassies abroad. In this case, some delay is very likely between the date of migration and the registration, and it is also likely that only permanent moves abroad are registered. ${ }^{2}$

To overcome some of the drawbacks of official statistics, we use a combination of statistical sources. For entries into Spain, we rely on the Estadistica de Variaciones Residenciales, which provide longer series. For outflows, we use as the Estadistica de Migraciones, which provides better information during the available sample period. Both datasets provide information on gender, age, nationality, country of birth, 
province of origin (destination), and country of destination (origin) of migrants. ${ }^{3}$ In the case of foreign nationals leaving Spain, we assume that the country of destination coincides with the country of birth, since available evidence suggests that this is a good approximation of reality. ${ }^{4}$ Moreover, by restricting one destination for each place of birth, the empirical strategy is simpler.

Data on the population of foreign nationals in the origin country is obtained from the World Economic Outlook database. Data on the population of Spanish and foreign nationals residing in Spain is obtained from municipal registers (Padrón de Habitantes). ${ }^{5}$ Information on the stock of nationals residing abroad is taken from the registers of Spanish consulates and embassies gathered by the INE since 2009 (Padrón de Españoles Residentes en el Extranjero), which provide information on the country of birth, province of last residence, province of birth and country of destination.

\subsection{Main historical and stylized facts}

Spain had net migration outflows throughout most of the 20th century (Table 1). At the beginning of the 20th Century, there were huge outflows to South America, mostly to Argentina, while migration inflows were negligible. Those moves were triggered by several factors: (i) the free movement laws enacted in Spain and in destination countries in the second half of the 19th century; (ii) a growing population, due to the decrease in mortality at the end of the 19th century that was followed by a subsequent decrease in fertility (Spain's population almost doubled between 1857 and 1950, from 15 million to 27 million); (iii) economic stagnation, with the average annual growth rate of GDP per capita in real terms estimated to have been slightly below $1 \%$ between 1850 and 1950; and (iv) a turbulent political situation in the period 1898-1939. However, migration outflows came to a standstill in the wake of the First World War and the global crisis of the 1930s and after the Spanish civil war (1936-1939) migration from Spain was banned. When migration abroad was freely allowed again in 1946, initially, almost $100 \%$ of the total outflows went to South America, although they were smaller than those registered at the beginning of the XXth Century.

Since 1950 and with regard to migration flows, there are three different periods.

\subsubsection{Early emigration (1950-1989)}

Early in this period, the main destination was South America, which attracted some 50 thousand migrants per year, followed in the 1960s by Europe (mostly France, Germany, and Switzerland), with average annual flows of around 170 thousand migrants (see Table 1). In the 1960s, some $80 \%$ of total emigrants went to Europe, reaching a peak of 7 per thousand of the total population mid-decade. Emigration to Europe was mostly driven by the shortage of unskilled workers to fill jobs in agriculture or manufacturing in the destination countries. From the mid1960s, these emigration flows declined, due first to economic growth in Spain and subsequently to the higher barriers to immigration erected in the destination countries following the oil crisis of the early 1970s. However, net positive outflows continued, although at a slower pace, during the first half of the 1980s when Spain was still suffering significant employment losses. 
Table 1 Immigration and emigration by nationality and country of birth

\begin{tabular}{|c|c|c|c|c|c|c|c|c|c|c|}
\hline & \multicolumn{5}{|c|}{ Flow (persons) } & \multicolumn{5}{|c|}{ Ratio respect to population ('000) } \\
\hline & \multirow[t]{2}{*}{ Total } & \multicolumn{2}{|c|}{ Spanish nationality } & \multirow{2}{*}{$\begin{array}{l}\text { Spanish } \\
\text { nationality } \\
\text { Total }\end{array}$} & \multirow{2}{*}{$\begin{array}{l}\text { Foreign } \\
\text { nationality } \\
\text { Total }\end{array}$} & \multirow[t]{2}{*}{ Total } & \multicolumn{2}{|c|}{$\begin{array}{l}\text { Spanish } \\
\text { nationality }\end{array}$} & \multirow{2}{*}{$\begin{array}{l}\text { Spanish } \\
\text { nationality } \\
\text { Total }\end{array}$} & \multirow{2}{*}{$\begin{array}{l}\text { Foreign } \\
\text { nationality } \\
\text { Total }\end{array}$} \\
\hline & & $\begin{array}{l}\text { Born in } \\
\text { Spain }\end{array}$ & $\begin{array}{l}\text { Born } \\
\text { abroad }\end{array}$ & & & & $\begin{array}{l}\text { Born in } \\
\text { Spain }\end{array}$ & $\begin{array}{l}\text { Born } \\
\text { abroad }\end{array}$ & & \\
\hline \multicolumn{11}{|c|}{ Immigration } \\
\hline 1996 & 29.895 & 9.359 & 3.850 & 13.209 & 16.686 & 0.8 & 0.2 & 6.8 & 0.3 & 28.6 \\
\hline 1997 & 57.877 & 15.401 & 6.860 & 22.261 & 35.616 & 1.4 & 0.3 & 10.3 & 0.5 & 59.2 \\
\hline 1998 & 81.227 & 15.881 & 8.151 & 24.032 & 57.195 & 2.0 & 0.4 & 13.7 & 0.6 & 89.8 \\
\hline 1999 & 127.365 & 17.488 & 10.755 & 28.243 & 99.122 & 3.2 & 0.5 & 18.1 & 0.7 & 132.3 \\
\hline 2000 & 362.468 & 17.608 & 13.979 & 31.587 & 330.881 & 8.9 & 0.5 & 21.8 & 0.8 & 358.1 \\
\hline 2001 & 414.772 & 9.522 & 11.202 & 20.724 & 394.048 & 10.1 & 0.2 & 16.7 & 0.5 & 287.5 \\
\hline 2002 & 483.260 & 17.836 & 22.339 & 40.175 & 443.085 & 11.6 & 0.5 & 31.7 & 1.0 & 224.0 \\
\hline 2003 & 470.010 & 19.209 & 21.277 & 40.486 & 429.524 & 11.0 & 0.5 & 28.4 & 1.0 & 161.2 \\
\hline 2004 & 684.561 & 19.941 & 18.776 & 38.717 & 645.844 & 15.8 & 0.5 & 23.9 & 1.0 & 212.8 \\
\hline 2005 & 719.284 & 18.476 & 18.097 & 36.573 & 682.711 & 16.3 & 0.5 & 21.9 & 0.9 & 183.0 \\
\hline 2006 & 840.844 & 18.944 & 18.929 & 37.873 & 802.971 & 18.8 & 0.5 & 21.5 & 0.9 & 193.8 \\
\hline 2007 & 958.266 & 19.010 & 18.722 & 37.732 & 920.534 & 21.2 & 0.5 & 19.9 & 0.9 & 203.7 \\
\hline 2008 & 726.009 & 17.068 & 16.713 & 33.781 & 692.228 & 15.7 & 0.4 & 16.1 & 0.8 & 131.4 \\
\hline 2009 & 498.977 & 15.887 & 13.748 & 29.635 & 469.342 & 10.7 & 0.4 & 12.1 & 0.7 & 83.1 \\
\hline 2010 & 464.443 & 15.658 & 17.451 & 33.109 & 431.334 & 9.9 & 0.4 & 14.3 & 0.8 & 75.0 \\
\hline 2011 & 454.686 & 18.678 & 19.726 & 38.404 & 416.282 & 9.6 & 0.5 & 14.8 & 0.9 & 72.4 \\
\hline 2012 & 370.515 & 17.767 & 16.638 & 34.405 & 336.110 & 7.8 & 0.4 & 11.4 & 0.8 & 58.6 \\
\hline 2013 & 342.390 & 18.197 & 17.157 & 35.354 & 307.036 & 7.3 & 0.5 & 11.0 & 0.9 & 55.4 \\
\hline 2014 & 380.659 & 20.205 & 18.950 & 39.155 & 341.504 & 8.1 & 0.5 & 11.0 & 0.9 & 68.0 \\
\hline \multicolumn{11}{|c|}{ Emigration } \\
\hline \multicolumn{11}{|c|}{ Period of early emigration 1960s } \\
\hline 1960 & 105.420 & & & & & 3.5 & & & & \\
\hline 1961 & 176.821 & & & & & 5.7 & & & & \\
\hline 1962 & 216.381 & & & & & 6.9 & & & & \\
\hline 1963 & 200.539 & & & & & 6.3 & & & & \\
\hline 1964 & 230.124 & & & & & 7.2 & & & & \\
\hline 1965 & 203.609 & & & & & 6.3 & & & & \\
\hline 1966 & 155.093 & & & & & 4.8 & & & & \\
\hline 1967 & 89.484 & & & & & 2.7 & & & & \\
\hline \multicolumn{11}{|c|}{ Period of recent emigration } \\
\hline 2002 & & 26.102 & 3.572 & 29.674 & & & 0.67 & 5.07 & 0.74 & \\
\hline 2003 & & 13.870 & 2.120 & 15.990 & & & 0.35 & 2.83 & 0.40 & \\
\hline 2004 & & 10.985 & 2.171 & 13.156 & & & 0.28 & 2.76 & 0.33 & \\
\hline 2005 & & 15.914 & 3.376 & 19.290 & & & 0.40 & 4.08 & 0.48 & \\
\hline 2006 & & 17.900 & 4.142 & 22.042 & & & 0.45 & 4.70 & 0.54 & \\
\hline 2007 & & 22.527 & 5.564 & 28.091 & & & 0.57 & 5.91 & 0.69 & \\
\hline 2008 & 288.432 & 25.461 & 8.044 & 33.505 & 254.927 & 6.2 & 0.64 & 7.75 & 0.82 & 48.38 \\
\hline 2009 & 380.118 & 26.334 & 9.656 & 35.990 & 344.128 & 8.1 & 0.66 & 8.53 & 0.88 & 60.92 \\
\hline 2010 & 403.379 & 29.204 & 10.953 & 40.157 & 363.221 & 8.6 & 0.73 & 8.97 & 0.97 & 63.19 \\
\hline 2011 & 409.034 & 40.150 & 15.321 & 55.472 & 353.562 & 8.7 & 1.00 & 11.49 & 1.34 & 61.47 \\
\hline
\end{tabular}


Table 1 Immigration and emigration by nationality and country of birth (Continued)

\begin{tabular}{lllllllllll}
\hline 2012 & 446.606 & 38.749 & 18.518 & 57.267 & 389.339 & 9.4 & 0.97 & 12.64 & 1.38 & 67.87 \\
2013 & 532.303 & 48.136 & 25.193 & 73.329 & 458.974 & 11.3 & 1.20 & 16.11 & 1.76 & 82.75 \\
2014 & 409.344 & 50.249 & 28.536 & 78.785 & 330.559 & 8.8 & 1.26 & 16.49 & 1.89 & 65.80 \\
\hline
\end{tabular}

Sources: Emigration from Spain during the period of early migration is from Nadal (1984) and Garcia Fernandez (1965). It is computed as the sum of emigration to America based on passengers on ships and planes and emigration to Europe based on destination countries' statistics population in that period is from census data 1960 and 1970 . The years in between are the result of a geometric interpolation immigration from municipal registers (Estadística de Variaciones Residenciales). Emigration from municipal registers (Estadística de Variaciones Residenciales) until 2007 and Estadística de migraciones since 2008 Population since 1996 comes from municipal registers (Padron Continuo)

\subsubsection{Immigration: the boom (1990-2007) and recent trends (2008-2014)}

From the early 1990s, and most noticeably after 1997, Spain became a destination country for immigrants. Inflows increased steadily, from under 30 thousand per year in 1996 to 958 thousand in 2007, when foreigners amounted to more than $12 \%$ of the total population (see Table 1). During the expansion, foreign immigrants were mostly Europeans, closely followed by Latin Americans (mostly Peruvians and Bolivians) and Africans (mostly Moroccans). The onset of the crisis brought about a sudden shift in this trend, and in 2008 and 2009, European entries came to a sudden standstill, although since 2010, their share has returned to precrisis levels. During those years, the number of immigrants from the Americas continued to decline, while the number of immigrants from Africa and Asia rose somewhat as a share of the total.

As for inflows of Spanish nationals, during the 1980s and the early 1990s, most of them were Spaniards born in Spain, a clear sign of return migration. However, later in the 1990s, the composition changed due to a big increase in the number of Spaniards born abroad coming to Spain. Since Spanish nationality is acquired through parental nationality, regardless of the country of birth, it is likely that many foreigners (in the sense of people who had never lived in Spain before) were immigrating under Spanish nationality, so that these inflows should not be considered as the consequence of return migration. Moreover, inflows of Spanish nationals born in Spain were relatively inelastic to economic conditions, in contrast with the inflows of foreigners. As for the impact of the crisis, there was a rise in the number of Spanish nationals returning from Asia and Africa, while in the case of Spaniards born abroad, the most noticeable development is a further increase in the share of immigrants from the Americas.

\subsubsection{Emigration: the crisis (2008-2014)}

Migration outflows started to increase in 2007, and since 2010, outflows have amounted to more than 400 thousand per year (slightly below $1 \%$ of the total domestic population), which is, both in absolute and relative terms, the highest level of emigration in Spanish history (Table 1). This is mostly due to the high mobility of foreign nationals. Indeed, they make up the great majority of migration outflows: in 2012, approximately $5 \%$ of foreigners residing in Spain left the country, while less than 1 per thousand of Spaniards born in Spain emigrated. For the latter, migration outflows are still smaller than those registered in the 1960s, ${ }^{6}$ although between 2011 and 2014, outflows have not been offset by inflows, so Spain is now recording net migration outflows of nationals for the first time since the 1970s (net outflows in 2012 are estimated at around 70 thousand). 
Moreover, since 2007, there are also net migration outflows of Spanish-born Spaniards; the numbers are low, but migration outflows for this population group are accelerating. Preliminary data available for the first half of 2015 point to a further increase in exits, up to 32,980, while 51,267 was the number for the complete year 2014. Most foreigners went to Europe and South America, while Spaniards born in Spain overwhelmingly decide to migrate to Europe. Although the crisis has had little impact on the choice of destination countries for foreigners, in the case of Spaniards born in Spain, it has increased the share of outflows to Europe (mostly Germany and the UK) and to the USA.

\section{Estimating the impact of unemployment on migration inflows and outflows}

Apart from many geopolitical factors (wars, natural catastrophes, search for political asylum), economic factors play a very important role at determining international migration inflows and outflows. A very wide literature has highlighted many of them, such as wage differentials, employment conditions, migration costs, both pecuniary and cultural, the diversification of risk within family members, differences in relative prices between host and home country, the accumulation of human capital, the improvement of the health status, or the willingness to reach a savings target to overcome capital constraints in the home country (Massey et al. 1993; Dustmann and Weiss 2007). More recently, global value chains have also generated a new sort of temporary movements. Finally, the consolidation of international migration is usually related to network effects that support transnational movements generated by particular institutions in the host and the receiving country.

In order to analyze the Spanish case, we focus on the differential of employment conditions between origin and destination countries. Our strategy is similar to Grogger and Hanson's (2011), who relate the log odds of residing in country $h$ for a person from country $s$ is thought to be determined by absolute differences in earnings between the two countries and by the cost of migrating that is idiosyncratic to that particular country of origin and destination pair. However, when considering migration to or from Spain, earnings do not appear to be a good proxy for economic opportunities, since high unemployment rates have been prevalent, ranging between 8 and $26 \%$ in the period 2000-2015. Indeed, changes in unemployment appear to be more appropriate than changes in wages to measure how economic opportunities evolve over time, particularly when, as has happened during the current recession, wages have reacted slowly to the worsening of the economic situation due to significant real and nominal rigidities. ${ }^{7}$ Since Harris and Todaro (1970), many other papers in the literature have included unemployment rate differentials as either push or pull factors to explain migration flows (see, for instance Zavodny 1997; Pedersen et al. 2008; Beine et al. 2013; Bertoli et al. 2013a).

In the spirit of Grogger and Hanson's (2011) approach, migration flows are assumed to respond symmetrically to changes in relative economic opportunities, so that the effects on migration flows of a change in relative economic conditions in one particular country should disappear completely when the initial economic conditions are restored. In this regard, the recent experience in Spain shows that this might not be the case. The sharp drop in unemployment (from around 23 to 11 \%) between 1995 and 2001 drove up the share of foreigners in the Spanish economy. Subsequently, unemployment 
remained roughly constant, but the foreign population continued to grow. In 2007, the Spanish unemployment rate headed up again, but the foreign population continued to increase, before declining slightly in 2012.

It seems, therefore, that analyzing changes in the stock of foreign nationals in Spain in the current situation needs a more flexible specification. For that reason, we estimate the effects of economic conditions on both entries of foreigners and exits of Spaniards separately (see Fig. 1). The sharp decline in unemployment between 1995 and 2001 prompted an increase in the number of inflows of foreigners in Spain. These inflows continued to rise until 2007, even though the unemployment rate was quite steady, due to decreasing migration costs and as result of the increase in the stock of migrants in Spain that precluded a generalized preference for Spain rather than other alternative destinations (Bertoli et al. 2013b). As from 2007, inflows decreased as unemployment rose. It is noteworthy that the impact of changes in unemployment on migration inflows is similar to that observed in the 1990s, but at a higher level of unemployment. In turn, in these last 4 years, outflows of both foreign and nationals have also increased as unemployment has risen at a similar pace.

One would be tempted to ask whether the current level of outflows of Spaniards has been enough to decrease the costs of emigration for this particular socioeconomic group as it happened for foreigners between 2001 and 2007. In particular, Fig. 2 illustrates that after a small decline in unemployment rates in 2014, emigrations of Spaniards born in Spain kept growing whereas those of foreigners already declined. In particular, the emigration rate of Spaniards born in Spain (per thousands) increased in 2014 from 1.2 to 1.35 whereas that of foreigners decreased from 83 to 65 (for further details, see Izquierdo et al. 2014).

This descriptive evidence suggests that even though bilateral inflows and outflows might respond to economic conditions as theory predicts, changes in costs of migration may blur the contemporaneous responses of the stock of migrants to economic conditions somewhat. To test quantitatively the importance of these mechanisms, we follow Bertoli et al (2013a) and relate the log odds of immigrating (I) (fraction of entries from one country of birth to one region divided by the corresponding population residing in that country of origin). ${ }^{8}$ We also do the same for emigrating $(E)$ (fraction of exits from one country of birth to one country of destination divided by the corresponding population residing in that region) to unemployment differentials $(U)$ and to the costs of immigration/emigration between origin $(h)$ and destination $(s) .{ }^{9}$ Using the superscript $f$ to denote foreigners and $e$ to denote Spaniards, our regression specifications are:

$$
\begin{aligned}
& \ln I_{h s t}^{f}=\alpha_{0}+\alpha_{1}\left(U_{h t}-U_{s t}\right)+\lambda_{t} c_{t}+\lambda_{h} c_{h}+\lambda_{s} c_{s} \\
& \ln E_{h s t}^{e}=\gamma_{0}+\gamma_{1}\left(U_{h t}-U_{s t}\right)+\kappa_{t} c_{t}+\kappa_{h} c_{h}+\kappa_{s} c_{s}
\end{aligned}
$$

In subsequent specifications, we will allow different elasticities for the unemployment rate at origin and destination. We proxy the cost of emigration $(c)$ in different ways (separate dummies for each origin country and for each destination region or dummies for time dummies coupled with a dyad country/region). We also include as covariates the time dummies $\left(c_{t}\right)$.

The literature has identified two problems with specifications such as (1)-(2): first, the potential bias introduced by the existence of zeros in emigration/immigration rates 

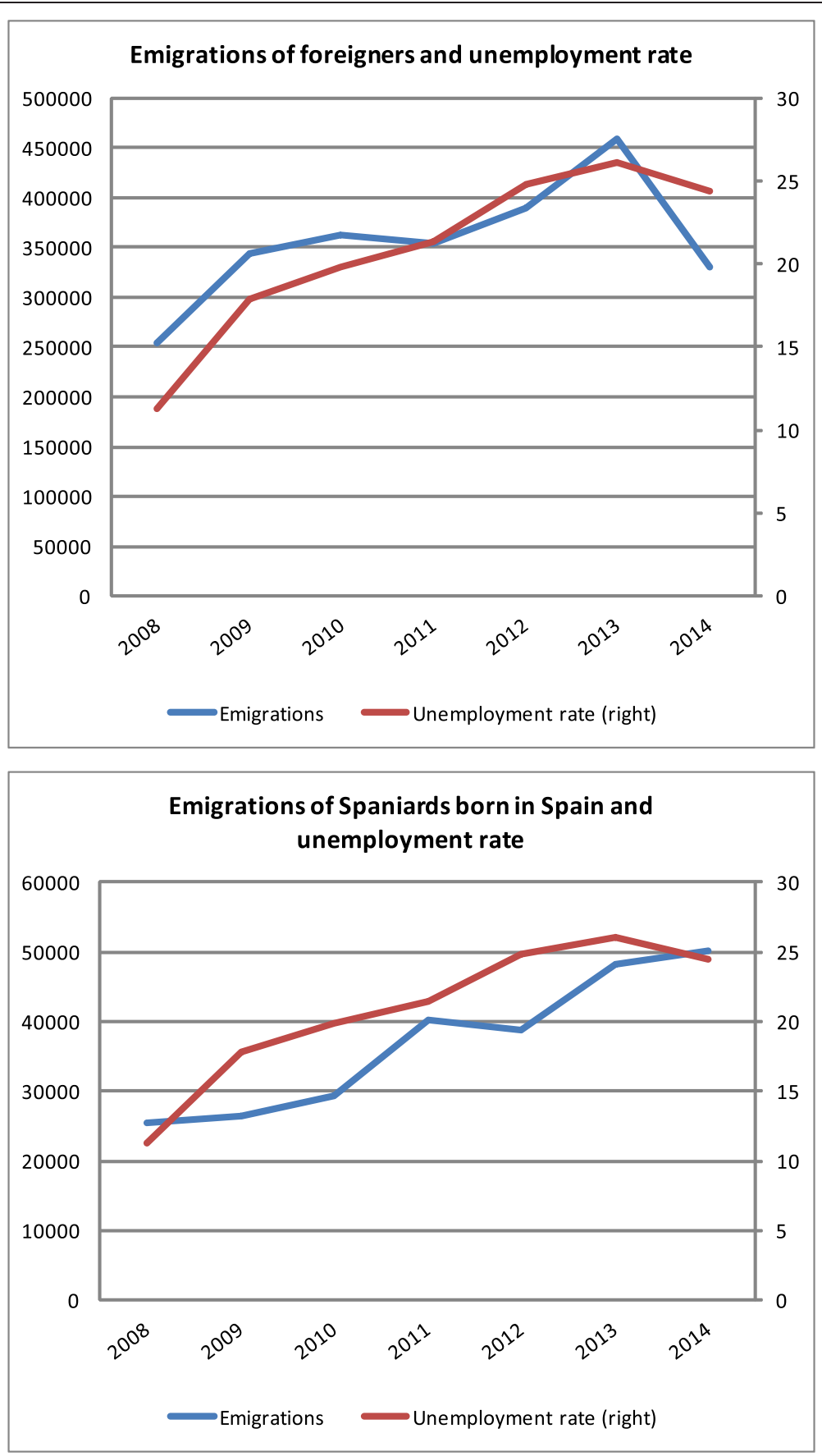

Fig. 2 Recent emigration by nationality and place of birth and unemployment rate

for a sizeable group of country pairs over time and second, multilateral resistance to migration, that is, the existence of positive correlation between unemployment rates of alternative origins. ${ }^{10}$

Regarding the problem of inexistent flows, we consider bilateral movements between a given country and a Spanish region (Comunidad Autónoma) in one particular year during the period 1998-2012 for entries and 2008-2012 for exits. In our databases, considering both entries and exits of foreign and Spanish nationals, more than $15 \%$ of 
the cells are nil. To avoid the problems associated to the use of Poisson's methods to treat the problem of zeros, we eliminate the cells with smaller flows from the sample. ${ }^{11}$

Regarding multilateral resistance to migration, autocorrelation of residuals in (1)-(2) cannot be ruled out. In consequence, the estimated coefficient of unemployment in the origin country might be upward biased. To solve this problem, we follow Bertoli et al. (2013a) who add as an auxiliary variable the cross-sectional (over countries) average of the dependent and independent variables, using monthly observations, to incorporate the changes in the willingness to migrate to alternative destinations (common correlated effect (CCE)). We will do the same averaging over countries and regions of destination. If there is correlation between unemployment rates of alternative origin countries, the estimated coefficient of the impact of unemployment rate in the origin country on foreign migration flows is biased upwards. This is the case because we do not observe all bilateral movements, and the flows between two different origin countries that present a certain correlation in unemployment affect the flows between that country and Spain. In principle, this problem should be less problematic for Spaniards since we have all the relevant information for this particular group and internal migration is not very much affected by unemployment differentials (Bentolila and Dolado 1991; Antolín and Bover 1997). In order to check the above hypothesis, we also estimate Eq. (1) on internal migrations showing that they do not increase with unemployment differentials across regions. ${ }^{12}$ Multilateral resistance to migration is not relevant to identify the coefficient of the unemployment rate of the regions in Spain. Indeed, there is a high correlation of unemployment among Spanish regions, and it is likely that foreigners in a first stage choose Spain and decide to go to one particular region balancing many other reasons such as the size of the community of foreigners there. ${ }^{13}$ When we apply this CCE methodology at the regional level in (1), the autocorrelation disappears for foreign entries.

Finally, to check the endogenous component of migration inflows, we will relate them to the decrease on the costs of emigration once there are networks of migrants abroad. In 1995, there were almost no foreigners in Spain, but the increase in foreign population took place very rapidly, so that network effects seem likely to have operated. Thus, we extend the specification of the immigration equation for Spain to include the lag of the stock of migrants of the same nationality (or who depart from a particular region in Spain) who reside in the corresponding region in Spain (or who reside in the corresponding potential destinations abroad) $\left(S_{h s t-1}\right) .^{14}$

$$
\begin{aligned}
& \ln I_{h s t}^{f}=\alpha_{0}+\alpha_{1}\left(U_{h t}-U_{s t}\right)+\alpha_{2} S_{h s t-1}+\lambda_{t} c_{t}+\lambda_{h} c_{h}+\lambda_{s} c_{s} \\
& \ln E_{h s t}^{e}=\gamma_{0}+\gamma_{1}\left(U_{h t}-U_{s t}\right)+\gamma_{2} S_{h s t-1}+\kappa_{t} c_{t}+\kappa_{h} c_{h}+\kappa_{s} c_{s}
\end{aligned}
$$

When running the abovementioned specification, it seems that there is no enough variation in the stock of migrants left when we control for both time dummies and the pairs of country of origin and region of destination. This is the case because during the period of analysis, and once we control for the average location preference of any country of origin, all stocks increase over time. Therefore, we will run specification (3)-(4) only including separately time, country of origin, and region of destination dummies.

Since the stock and the flows of migrants might not be fully consistent because they come from different data sources, and given that we have a pretty large time series 
(15 years) for inflows of foreigners, we also run a dynamic panel model to analyze the endogenous component of those inflows, as follows:

$$
\ln I_{h s t}^{f}=\alpha_{0}+\alpha_{1}\left(U_{h t}-U_{s t}\right)+\alpha_{3} \ln I_{h s t-1}^{f}+\lambda_{t} c_{t}+\lambda_{h} c_{h}+\lambda_{s} c_{s}
$$

We use the results as a consistent device to simulate the decrease in unemployment rate necessary to reduce inflow rates for Spaniards born in Spain. In order to estimate (5), we have to take into account the typical problems of estimating a dynamic panel with fixed effects and that is the reason why we will follow Arellano and Bond (1991) instrumenting the autocorrelation term with past immigration flows. In this case, since the regression is estimated in differences (6), it does not matter whether we include separate country of origin and region of destination dummies or the pairs of country of origin/destinations.

\section{Main results}

\subsection{Unemployment}

Table 2 reports the estimates of the log odds of foreign migration inflows to Spain. The first two columns refer to the estimates corresponding to the specification with fixed effects and time dummies; columns 3 and 4 estimates present estimates using auxiliary regressors dealing with multilateral resistance to migration (CCE). Under the former specification, an increase of $10 \mathrm{pp}$ in the unemployment rate of the destination region relative to the origin country is associated to a decrease of inflow rates to Spain of $0.3 \mathrm{pp}$. Since multilateral resistance to migration generates an upward bias on the impact of the origin country unemployment to inflows, estimates decreased slightly under the specification with auxiliary regressions, where the decrease of inflows associated to an increase of $10 \mathrm{pp}$ in the unemployment rate is only of $0.1 \mathrm{pp} .{ }^{15}$

Columns 5 to 8 refer to outflows from Spain of Spaniards born in Spain. Columns 5 and 6 show that a decrease in the unemployment differential rate of $10 \mathrm{pp}$ is associated to a rise of the outflows of $0.36 \mathrm{pp}$, and this estimate does not change substantially under the specification with auxiliary regressors (CCE in columns 7 and 8). This is not surprising since, as commented in the previous section, multilateral resistance to migration is not that relevant when considering outflows from different regions in Spain. In view of the above numbers, one might suggest that Spaniards born in Spain have a similar response to unemployment differentials than foreigners. Hence, the big difference in the observed magnitude of outflows between Spaniards and foreigners is better captured by differences in the constant, and the set of dummies, so it should be attributed to the different costs of migration of the two groups.

Tables 3, 4, 5, and 6 repeat the same estimation exercise separating unemployment in the origin country and regional unemployment. This is informative because there is a notable correlation of unemployment across Spanish regions and since the proposed specification incorporates time dummies, the estimates of the coefficients corresponding to the differences of unemployment rates might be biased. This is the reason why the first two columns of each table present estimates only estimates from considering the unemployment rate in the origin country, a specification more comparable to those in previous papers analyzing only 
Table 2 Log odds of immigrating to Spain by foreigners and emigrating from Spain by Spaniards born in Spain

\begin{tabular}{|c|c|c|c|c|c|c|c|c|}
\hline \multirow[b]{3}{*}{ Variables } & \multicolumn{4}{|c|}{ Entry of foreigners } & \multicolumn{4}{|c|}{ Exit of Spaniards born in Spain } \\
\hline & \multicolumn{2}{|l|}{ Fixed effects } & \multicolumn{2}{|l|}{ CCE } & \multicolumn{2}{|l|}{ Fixed effects } & \multicolumn{2}{|l|}{ CCE } \\
\hline & $(1)$ & (2) & (3) & (4) & (5) & (6) & (7) & (8) \\
\hline \multirow[t]{2}{*}{$\overline{U(C C A A)-U(c o u n t r y)}$} & -0.02967 & -0.02920 & -0.01029 & -0.00951 & 0.03624 & 0.03661 & 0.02953 & 0.04394 \\
\hline & $(0.00001)^{* *}$ & $(0.00001)^{* *}$ & $(0.00001)^{* *}$ & $(0.00001)^{* *}$ & $(0.00285)^{* *}$ & $(0.00201)^{* *}$ & $(0.00331)^{* *}$ & $(0.00175)^{* *}$ \\
\hline Time dummies & Yes & Yes & Yes & No & Yes & Yes & Yes & No \\
\hline Country dummies & Yes & No & Yes & No & Yes & No & Yes & No \\
\hline Region dummies & Yes & No & Yes & No & Yes & No & Yes & No \\
\hline Pair country/region dummies & No & Yes & Yes & Yes & No & Yes & Yes & Yes \\
\hline Auxiliary regressors & No & No & Yes & Yes & No & No & Yes & Yes \\
\hline \multirow[t]{2}{*}{ Constant } & -8.184 & -9.904 & -0.095 & -2.042 & -5.737 & -5.181 & -6.245 & -0.84414 \\
\hline & $(0.00025)^{* *}$ & $(0.00011)^{* *}$ & $(0.00171)^{* *}$ & $(0.00022)^{* *}$ & $(0.04315)^{* *}$ & $(0.01081)^{* *}$ & $(0.38672)^{* *}$ & $(0.10115)^{* *}$ \\
\hline R-squared & 0.88 & 0.71 & 0.89 & 0.78 & 0.76 & 0.19 & 0.79 & 0.30 \\
\hline Observations & 6938 & 6938 & 6938 & 6938 & 2267 & 2267 & 2267 & 2267 \\
\hline
\end{tabular}

Source: In columns 1 to 4, the dependent variable is the logarithm of entries from Estadística de Variaciones Residenciales by country of birth and region of destination in a particular year (1998-2012) over the

population in the country of birth in the corresponding year (WEO) in thousands. In columns 5 to 8 , the dependent variable is the logarithm of exits from Estadística de Variaciones Residenciales by region of residence and country of destination (2002-2012) over the population in the region of residence (padron) in thousands. Unemployment rates of regions in Spain are from the labour force survey and unemployment

in origin countries at the WEO. The auxiliary regressors are the cross country average of all dependent and independent variables. Observations are weighted by the population of the origin country. Standard errors

in parentheses

${ }^{*} p<0.05$; ${ }^{* *} p<0.01$ 
Table 3 Log odds of immigrating to Spain by foreigners. Fixed effects

\begin{tabular}{|c|c|c|c|c|}
\hline \multirow[b]{3}{*}{ Variables } & \multicolumn{4}{|c|}{ Entry of foreigners } \\
\hline & \multicolumn{4}{|c|}{ Fixed effects } \\
\hline & $(1)$ & (2) & (4) & (5) \\
\hline \multirow[t]{2}{*}{ U(country) } & 0.04921 & 0.04948 & 0.04921 & 0.04948 \\
\hline & $(0.00002)^{* *}$ & $(0.00001)^{* *}$ & $(0.00002)^{* *}$ & $(0.00001)^{* *}$ \\
\hline \multirow[t]{2}{*}{$U(C C A A)$} & & & -0.01041 & -0.00919 \\
\hline & & & $(0.00002)^{* *}$ & $(0.00001)^{* *}$ \\
\hline Time dummies & Yes & Yes & Yes & No \\
\hline Country dummies & Yes & No & Yes & No \\
\hline Region dummies & Yes & No & Yes & No \\
\hline Pair country/region dummies & No & Yes & Yes & Yes \\
\hline Auxiliary regressors & No & No & Yes & Yes \\
\hline \multirow[t]{2}{*}{ Constant } & -8.938 & -1.041 & -8.719 & -1.029 \\
\hline & $(0.00021)^{* *}$ & $(0.00012)^{* *}$ & $(0.00042)^{* *}$ & $(0.00020)^{* *}$ \\
\hline R-squared & 0.88 & 0.72 & 0.88 & 0.72 \\
\hline Observations & 6938 & 6938 & 6938 & 6938 \\
\hline
\end{tabular}

Source: The dependent variable is the logarithm of entries from Estadística de Variaciones Residenciales by country of birth and region of destination in a particular year (1998-2012) over the population in the country of birth in the corresponding year (WEO) in thousands. Unemployment rates of regions in Spain are from the labour force survey and unemployment in origin countries at the WEO. The auxiliary regressors are the cross country average of all dependent and independent variables. Observations are weighted by the population of the origin country. Standard errors in parentheses

${ }^{*} p<0.05 ;{ }^{* *} p<0.01$

Table 4 Log odds of immigrating to Spain by foreigners. CCE

\begin{tabular}{|c|c|c|c|c|}
\hline \multirow[b]{3}{*}{ Variables } & \multicolumn{4}{|c|}{ Entry of foreigners } \\
\hline & \multicolumn{4}{|l|}{ CCE } \\
\hline & $\overline{(1)}$ & (2) & (4) & (5) \\
\hline \multirow[t]{2}{*}{ U(country) } & 0.03105 & 0.03081 & 0.03103 & 0.03079 \\
\hline & $(0.00005)^{* *}$ & $(0.00003)^{* *}$ & $(0.00005)^{* *}$ & $(0.00003)^{* *}$ \\
\hline \multirow[t]{2}{*}{ U(CCAA) } & & & -0.01039 & -0.00907 \\
\hline & & & $(0.00002)^{* *}$ & $(0.00001)^{* *}$ \\
\hline Time dummies & Yes & Yes & Yes & No \\
\hline Country dummies & Yes & No & Yes & No \\
\hline Region dummies & Yes & No & Yes & No \\
\hline Pair country/region dummies & No & Yes & Yes & Yes \\
\hline Auxiliary regressors & No & No & Yes & Yes \\
\hline \multirow[t]{2}{*}{ Constant } & -0.14053 & -2.162 & -0.04124 & -2.147 \\
\hline & $(0.00298)^{* *}$ & $(0.00034)^{* *}$ & $(0.00298)^{* *}$ & $(0.00034)^{* *}$ \\
\hline R-squared & 0.90 & 0.78 & 0.90 & 0.79 \\
\hline Observations & 6938 & 6938 & 6938 & 6938 \\
\hline
\end{tabular}

Source: The dependent variable is the logarithm of entries from Estadistica de Variaciones Residenciales by country of birth and region of destination in a particular year (1998-2012) over the population in the country of birth in the corresponding year (WEO) in thousands. Unemployment rates of regions in Spain are from the labour force survey and unemployment in origin countries at the WEO. The auxiliary regressors are the cross country average of all dependent and independent variables. Observations are weighted by the population of the origin country. Standard errors in parentheses

${ }^{*} p<0.05$; ${ }^{* *} p<0.01$ 
Table 5 Log odds of emigrating from Spain by Spaniards born in Spain. Fixed effects

\begin{tabular}{|c|c|c|c|c|}
\hline \multirow[b]{3}{*}{ Variables } & \multicolumn{4}{|c|}{ Exit of Spaniards born in Spain } \\
\hline & \multicolumn{4}{|c|}{ Fixed effects } \\
\hline & $(1)$ & (2) & (4) & (5) \\
\hline \multirow[t]{2}{*}{ U(country) } & -0.05733 & -0.05701 & -0.05729 & -0.05696 \\
\hline & $(0.00420)^{* *}$ & $(0.00296)^{* *}$ & $(0.00419)^{* *}$ & $(0.00295)^{* *}$ \\
\hline \multirow[t]{2}{*}{ U(CCAA) } & & & 0.01832 & 0.01923 \\
\hline & & & $(0.00387)^{* *}$ & $(0.00273)^{* *}$ \\
\hline Time dummies & Yes & Yes & Yes & No \\
\hline Country dummies & Yes & No & Yes & No \\
\hline Region dummies & Yes & No & Yes & No \\
\hline Pair country/region dummies & No & Yes & Yes & Yes \\
\hline Auxiliary regressors & No & No & Yes & Yes \\
\hline \multirow[t]{2}{*}{ Constant } & -4.888 & -4.672 & -5.251 & -4.873 \\
\hline & $(0.03258)^{* *}$ & $(0.01968)^{* *}$ & $(0.08326)^{* *}$ & $(0.03462)^{* *}$ \\
\hline R-squared & 0.77 & 0.19 & 0.77 & 0.19 \\
\hline Observations & 2267 & 2267 & 2267 & 2267 \\
\hline
\end{tabular}

Source: The dependent variable is the logarithm of exits from Estadística de Variaciones Residenciales by region of residence and country of destination (2002-2012) over the population in the region of residence (padron) in thousands. Unemployment rates of regions in Spain are from the labour force survey and unemployment in origin countries at the WEO. The auxiliary regressors are the cross country average of all dependent and independent variables. Observations are weighted by the population of the region of origin in Spain. Standard errors in parentheses ${ }^{*} p<0.05 ;{ }^{* *} p<0.01$

analyzed one of the flows. Broadly speaking, the previous finding on the similar sensitivity of Spaniard and foreigner flows to unemployment rate remains valid. In particular, for foreigners, Table 3 shows that inflows to Spain are $0.5 \mathrm{pp}$ larger from those countries with higher unemployment rates by $10 \mathrm{pp}$. This elasticity is slightly decreased (0.3) when CCE is accounted for (Table 4). Results are quantitatively similar to Zavodny (1997) that did a similar exercise for the USA obtaining an elasticity of 0.04 for the unemployment rate of the origin country and to the more recent estimation of Bertoli et al. (2013b), although their results are not directly comparable to ours, since they specify the regression in terms of log of unemployment obtaining a coefficient for the unemployment in the origin country ranging between 0.729 and 0.400 with FE and 0.521-0.384 with CCE depending on the particular specification. If we run column 2 with the log of unemployment instead of unemployment, we obtain 0.62 with FE and 0.19 with CCE. Beine et al. (2013) obtained a slightly higher coefficient (around 0.15). The result is qualitatively consistent with the evidence on the sensitivity of international migration to economic conditions in the origin country found in many papers such as Hatton and Williamson (2002) and more recently in Ortega and Peri (2013).

On the other hand, despite the small variation across regions, the data is able to capture the importance of pull factors, and those regions with $10 \mathrm{pp}$ lower unemployment are able to capture $0.1 \mathrm{pp}$ more inflows (Tables 3 and 4). Finally, as for Spaniards born in Spain (Tables 5 and 6), the results show that the sensitivity to origin and destination unemployment rates is very similar and in particular not smaller than that estimated for foreigners. 
Table 6 Log odds of emigrating from Spain by Spaniards born in Spain. CCE

\begin{tabular}{|c|c|c|c|c|}
\hline \multirow[b]{3}{*}{ Variables } & \multicolumn{4}{|c|}{ Exit of Spaniards born in Spain } \\
\hline & \multicolumn{4}{|l|}{ CCE } \\
\hline & $(1)$ & (2) & (4) & (5) \\
\hline \multirow[t]{2}{*}{ U(country) } & -0.07086 & -0.06150 & -0.07091 & -0.06206 \\
\hline & $(0.00658)^{* *}$ & $(0.00735)^{* *}$ & $(0.00656)^{* *}$ & $(0.00730)^{* *}$ \\
\hline \multirow[t]{2}{*}{ U(CCAA) } & & & 0.02133 & 0.04422 \\
\hline & & & $(0.00410)^{* *}$ & $(0.00330)^{* *}$ \\
\hline Time dummies & Yes & Yes & Yes & No \\
\hline Country dummies & Yes & No & Yes & No \\
\hline Region dummies & Yes & No & Yes & No \\
\hline Pair country/region dummies & No & Yes & Yes & Yes \\
\hline Auxiliary regressors & No & No & Yes & Yes \\
\hline \multirow[t]{2}{*}{ Constant } & -7.258 & -1.298 & -7.758 & -1.870 \\
\hline & $(0.57809)^{* *}$ & $(0.17405)^{* *}$ & $(0.58854)^{* *}$ & $(0.17853)^{* *}$ \\
\hline R-squared & 0.79 & 0.32 & 0.79 & 0.33 \\
\hline Observations & 2267 & 2267 & 2267 & 2267 \\
\hline
\end{tabular}

Source: The dependent variable is the logarithm of exits from Estadística de Variaciones Residenciales by region of residence and country of destination (2002-2012) over the population in the region of residence (padron) in thousands. Unemployment rates of regions in Spain are from the labour force survey and unemployment in origin countries at the WEO. The auxiliary regressors are the cross country average of all dependent and independent variables. Observations are weighted by the population of the region of origin in Spain. Standard errors in parentheses ${ }^{*} p<0.05 ;{ }^{* *} p<0.01$

\subsection{Migration costs and network effects}

Columns 1-3 of Table 7 show that no matter the way we specify the incidence of relative unemployment in origin and destination country, migration rates increase whenever the stock of migrants is higher at destination. In particular, controlling for unemployment rates, pairs of countries/regions that have $1 \mathrm{pp}$ of a higher stock of migrants generate a higher migration inflow rate of $0.8 \mathrm{pp}$. This is a well-established fact; similar results are in Hatton and Williamson (2002) and Pedersen et al. (2008) although their corresponding estimates ( 0.43 and 0.36 , respectively) are slightly lower than ours. This could be the case because the recent immigration history in Spain started in 1995 with almost no immigrant settled in the country, something that may have generated a higher potential for endogenous growth since congestion effects are nil.

This network effect is even more pronounced for Spaniards born in Spain (see columns 4-6). In particular, controlling for unemployment, pairs of regions of origin and country of destination that have $1 \mathrm{pp}$ of a higher stock of Spaniards generate a higher immigration rate of $1.5 \mathrm{pp}$. Notice that results might be affected by the fact that the information registered in the Spanish consulates and embassies could be a very poor proxy of settlements abroad, since incoming migrants do not register immediately, something that does not happened with foreigners coming to Spain since they have many incentives to register in the municipal registers as soon as possible. ${ }^{16}$

As it has been said, emigration by Spaniards born in Spain is a new phenomenon and network effects could be starting to operate at full potential (embassy registers record just under 750,000 Spaniards born in Spain and living abroad in January 2015, which is less than $2 \%$ of the population). As a consequence, this mechanism generates a counterbalance for the recent relative improvement of the Spanish unemployment rate 
Table 7 Log odds of immigrating to Spain by foreigners or emigrating from Spain by Spaniards born in Spain as a function of stock of people from the same nationality in destination country

\begin{tabular}{|c|c|c|c|c|c|c|}
\hline \multirow[b]{3}{*}{ Variables } & \multicolumn{3}{|c|}{ Entry of foreigners } & \multirow{2}{*}{\multicolumn{3}{|c|}{$\begin{array}{l}\text { Exit of Spaniards born in Spain } \\
\text { Fixed effects }\end{array}$}} \\
\hline & \multicolumn{3}{|l|}{ Fixed effects } & & & \\
\hline & (1) & (2) & (3) & $\overline{(4)}$ & (5) & (6) \\
\hline \multirow[t]{2}{*}{ U(CCAA)-U(country) } & -0.02813 & & & 0.04627 & & \\
\hline & $(0.00001)^{* *}$ & & & $(0.00574)^{* *}$ & & \\
\hline \multirow[t]{2}{*}{ U(country) } & & 0.04739 & 0.04741 & & -0.07865 & -0.07894 \\
\hline & & $(0.00002)^{* *}$ & $(0.00002)^{* *}$ & & $(0.00927)^{* *}$ & $(0.00926)^{* *}$ \\
\hline \multirow[t]{2}{*}{$U(C C A A)$} & & & -0.00946 & & & 0.02630 \\
\hline & & & $(0.00002)^{* *}$ & & & $(0.00726)^{* *}$ \\
\hline \multirow{2}{*}{$\begin{array}{l}\text { Stock of immigrants pair country/ } \\
\text { region by population in origin } \\
\text { (in thousands) }\end{array}$} & 0.08518 & 0.08869 & 0.08976 & 0.14919 & 0.14924 & 0.14922 \\
\hline & $(0.00011)^{* *}$ & $(0.00011)^{* *}$ & $(0.00011)^{* *}$ & $(0.00479)^{* *}$ & $(0.00479)^{* *}$ & $(0.00479)^{* *}$ \\
\hline Time dummies & Yes & Yes & Yes & Yes & Yes & Yes \\
\hline Country dummies & Yes & Yes & Yes & Yes & Yes & Yes \\
\hline Region dummies & Yes & Yes & Yes & Yes & Yes & Yes \\
\hline Pair country/region dummies & No & No & No & No & No & No \\
\hline Auxiliary regressors & No & No & No & No & No & No \\
\hline \multirow[t]{2}{*}{ Constant } & -5.282 & -8.393 & -5.991 & -6.012 & -4.424 & -5.178 \\
\hline & $(0.00035)^{* *}$ & $(0.00021)^{* *}$ & $(0.00058)^{* *}$ & $(0.12207)^{* *}$ & $(0.07732)^{* *}$ & $(0.22205)^{* *}$ \\
\hline R-squared & 0.88 & 0.88 & 0.88 & 0.80 & 0.80 & 0.80 \\
\hline Observations & 6542 & 6542 & 6542 & 1080 & 1080 & 1080 \\
\hline
\end{tabular}

Source: In columns 1 to 3, the dependent variable is the logarithm of entries from Estadística de Variaciones Residenciales by country of birth and region of destination in a particular year (1998-2012) over the population in the country of birth in the corresponding year (WEO) in thousands. In columns 4 to 6 , the dependent variable is the logarithm of exits from Estadística de Variaciones Residenciales by region of residence and country of destination (2002-2012) over the population in the region of residence (padron) in thousands. Unemployment rates of regions in Spain are from the labour force survey and unemployment in origin countries at the WEO. The auxiliary regressors are the cross country average of all dependent and independent variables. Observations are weighted by the population of the origin country in (1)-(3) or the region of origin in Spain in (4)-(6). Standard errors in parentheses

${ }^{*} p<0.05 ;{ }^{* *} p<0.01$

leading to still persistently high emigration rates of Spaniards. To analyze the quantitative importance of this factor, we could take the previous results (Table 8) as granted and try to estimate the reduction in the unemployment rate that would stabilize emigration rates. This is straightforward; using Eq. (4) yields:

$$
\Delta\left(U_{h t}-U_{s t}\right)=\frac{\gamma_{2}}{\gamma_{1}} \Delta S_{h s t-1}
$$

During the last years, the stock of Spaniards living abroad has been increasing steadily, and in the last 2 years, the increase of the ratio has been around 0.7 (see Fig. 3). Thus, once we apply the abovementioned 0.7 to Eq. (6), one can understand why emigration rates continued increasing for Spaniards born in Spain at the same time that unemployment in Spain decreased (Fig. 2). In particular, in order to stop migration outflows, the unemployment rate should have decreased $4 \mathrm{pp}$ in 2014, instead of the actual drop of 1.75 pp. Moreover, it is expected that in 2015, emigration rates will continue increasing since unemployment rate according to official figures only decreased $2.3 \mathrm{pp}$, something insufficient to compensate for the size of this estimated network effect. 
Table 8 Log odds of immigrating to Spain by foreigners

\begin{tabular}{|c|c|c|c|}
\hline \multirow[b]{3}{*}{ Variables } & \multicolumn{3}{|c|}{ Entry of foreigners } \\
\hline & \multicolumn{3}{|c|}{ Arellano Bond } \\
\hline & $(1)$ & $(2)$ & (3) \\
\hline \multirow[t]{2}{*}{ U(CCAA)-U(country) } & -0.02620 & & \\
\hline & $(0.00109)^{* *}$ & & \\
\hline \multirow[t]{2}{*}{$U$ (country) } & & 0.02344 & -0.00210 \\
\hline & & $(0.00415)^{* *}$ & $(0.00423)$ \\
\hline \multirow[t]{2}{*}{$U(C C A A)$} & & & -0.03037 \\
\hline & & & $(0.00123)^{* *}$ \\
\hline \multirow[t]{2}{*}{ Lag. Log odds of immigrating to Spain by foreigners } & 0.61734 & 0.59858 & 0.59844 \\
\hline & $(0.00598)^{* *}$ & $(0.00663)^{* *}$ & $(0.00654)^{* *}$ \\
\hline \multirow[t]{2}{*}{ Constant } & -1.876 & -2.279 & -1.661 \\
\hline & $(0.03436)^{* *}$ & $(0.03930)^{* *}$ & $(0.04614)^{* *}$ \\
\hline R-squared & 0.88 & & \\
\hline Observations & 5988 & 5988 & 5988 \\
\hline
\end{tabular}

Source: The dependent variable is the logarithm of entries from Estadística de Variaciones Residenciales by country of birth and region of destination in a particular year (1998-2012) over the population in the country of birth in the corresponding year (WEO) in thousands. Unemployment rates of regions in Spain are from the labour force survey and unemployment in origin countries at the WEO. The auxiliary regressors are the cross country average of all dependent and independent variables. Observations are weighted by the population of the origin country. Standard errors in parentheses

${ }^{*} p<0.05 ;{ }^{* *} p<0.01$

To analyze the consistency of the previous results to other specifications, we estimate the endogenous component of migration followed by foreigners as in Eq. (6). This new approach is informative since, as mentioned previously, immigration flows of foreigners started in a moment when there were no foreigners in Spain, something similar to what is happening nowadays with Spaniards going abroad. Estimates show the persistence of immigration flows in Spain in the period of the creation of the foreigner networks with an autoregressive parameter of 0.6. Applying this parameter to the current emigration rates of Spaniards born in Spain leads to similar conclusions to the ones presented before. In particular, the unemployment rate in Spain should have decreased 5 pp in 2014

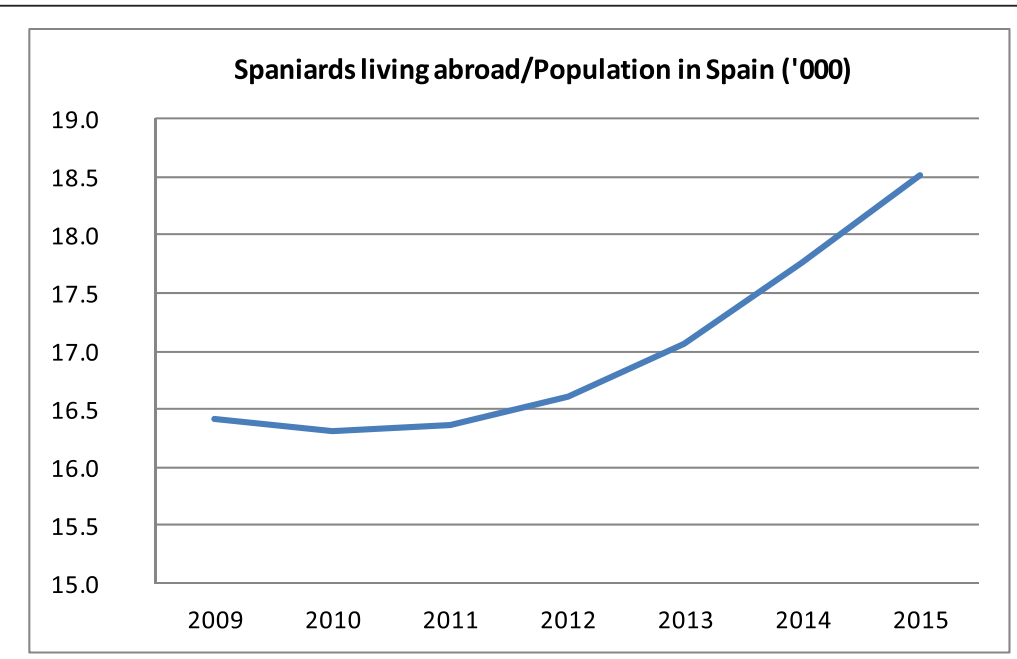

Fig. 3 Evolution of Spaniards born in Spain residing abroad 
in order to stop the growth in emigration rates in that particular year. Moreover, in 2015, emigration rates will continue increasing unless the unemployment rate in Spain would decrease by around $3 \mathrm{pp}$.

\section{Conclusions}

This paper provides a first look at the data on migration inflows and outflows in Spain during the Great Recession. Our results hint at a significant change in the scale and composition of migration inflows and outflows. In terms of scale, Spanish and foreign nationals show quite a similar response to unemployment developments, and the continuing low exit rate of Spaniards born in Spain can only be attributed to small network effects for Spanish emigrants. However, as we learned from the rapid creation of networks of foreign nationals in Spain that attracted many immigrants to Spain during the housing boom, this is a phenomenon that could develop quite rapidly, regardless of future labor market developments. In particular, the rapid creation of networks might counterbalance the effect of a fall in unemployment rates of around 3-4 pp for the following year.

The possibility of network effects starting to come into play for Spanish emigrants, so that many outflows would become permanent, is a potential threat to Spanish potential growth. This is especially true given that recent foreign migrants seem to be positively selected on education (see Izquierdo et al. 2014). ${ }^{17}$ This finding hints at the possibility of the start of a significant brain drain, which could exacerbate the effects of the crisis on potential output if it were to last too long.

\section{Endnotes}

${ }^{1}$ See, for instance, Garcia Fernandez (1965), Nadal (1984), and Instituto Español de Inmigración (1973).

${ }^{2}$ Since 2008, the INE has used alternative statistical techniques to improve the information held by municipal registers and has started to compile statistics on migrations whose microdata are not available to us.

${ }^{3}$ We have repeated all our computations using the Estadística de Variaciones Residenciales, obtaining qualitatively similar results. Those calculations are available upon request.

${ }^{4}$ According to the New Immigration Survey conducted in Spain in 2007, more than $85 \%$ of immigrants planning to leave in the next 5 years reported that they intended to return to their birth country. Moreover, according to the Estadistica de Migraciones, the great majority of migrants of different origins (more than $70 \%$ ) report that they return to their birth country. See the companion paper for more information on this issue.

${ }^{5}$ To obtain socioeconomic information of the stock, we use Labour Force Survey data.

${ }^{6}$ When return migration by foreign nationals was nonexistent.

${ }^{7}$ On the adjustment of unemployment and wages across Spanish regions in previous recessions, see Bentolila and Jimeno (1998). Having said that, unemployment figures might be a worse proxy of economic opportunities in other countries. Nevertheless, we preferred to use the same variable in both Spain and other potential origins/ destinations. 
${ }^{8}$ The corresponding population for foreigners is the country of origin population; for Spaniards of one particular region in one particular country it is the population residing in that country and who are from that particular region. The rates will be always expressed in thousands of people.

${ }^{9}$ Given the large disparities in unemployment rates across Spanish regions (see Chart 1), we consider the log odds of residing in a Spanish region (we have access to data on 17 regions) for one person of a particular country (we have access to data on some 80 countries).

${ }^{10}$ If there is correlation between unemployment rates of alternative destination countries, the estimated coefficient of the impact of unemployment rate in the origin country on migration flows is biased upwards.

${ }^{11}$ In the case of foreign nationals, for entries, we use a sample of 31 countries of birth out of 80 potential countries, which results in less than $2 \%$ of zeros in region/country of origin/year between 1998 and 2012, and for departures, we keep 37 countries of birth for the period 2008-2012 out of 99 potential countries, which results in less than $5 \%$ of zeros. For outflows of Spanish nationals, we keep 30 out of 97 potential destinations for the period 2008-2012, which results in $5 \%$ of zeros.

${ }^{12}$ Results are available upon request.

${ }^{13}$ Average correlation over time of across region unemployment is $86 \%$ between two regions, with the exception of the Basque Country which has an average correlation with the rest of $68 \%$.

${ }^{14}$ The stock is computed as the ratio between the stock of people residing abroad and the stock of people who did not migrate (in thousands).

${ }^{15}$ Bertoli et al. (2013b) analyzed a case study of Ecuadorian nationals moving to Spain, showing the importance of changes in future expectations to increase the willingness to move to a country.

${ }^{16}$ In particular, one might prefer not to lag the stock of Spaniards born in Spain residing abroad, since it is already lagged due to delays on the moment of registration. However, for the sake of comparability with previous results, we have preferred to maintain the same specification for both foreigners and Spaniards as in Eq. (4).

${ }^{17}$ Due to the lack of proper data, the paper cannot redo the exercise assuming different costs of migration by educational attainment. However, using alternative information from the Labour Force Survey, Izquierdo et al (2014) conclude that there is positive selection in those households residing in Spain that send a member of the household abroad.

Competing interests

The IZA Journal of Migration is committed to the IZA Guiding Principles of Research Integrity. The authors declare that they have observed these principles.

\section{Acknowledgements}

We would like to thank the anonymous referee and the editor for the useful remarks.

Responsible editor: Denis Fougère

Received: 11 November 2015 Accepted: 28 March 2016

Published online: 27 May 2016

References

Antolín P, Bover O. Regional migration in Spain: the effect of personal characteristics and of unemployment, wage and house price differentials using pooled cross-sections. Oxford Bull Econ Stat. 1997;59(2):215-35.

Arellano M, Bond S. Some tests of specification for panel data: Monte Carlo evidence and an application to employment equations. Rev Econ Stud. 1991;58(2):277. 
Beine M, Bourgeon P, Bricongne JC. Aggregate fluctuations and international migration, CESifo Working Paper Series 4379, CESifo Group Munich; 2013

Bentolila S, Dolado JJ. Mismatch and internal migration in Spain, 1962-1986. In: Padoa-Schioppa F, editor. Mismatch and Labour Mobility. Cambridge: Cambridge University Press; 1991.

Bentolila S, Jimeno JF. Regional unemployment persistence (Spain, 1976-1994). Labour Econ. 1998;5:25-51.

Bertoli S, Brücker H, Fernandez-Huertas J. The European crisis and migration to Germany: expectations and the diversion of migration flows, IZA discussion papers 7170, Institute for the Study of Labor (IZA). 2013 a.

Bertoli S, Fernandez-Huertas J, Ortega F. Crossing the border: self-selection, earnings, and individual migration decisions. J Dev Econ. 2013b;101:75-91.

Dustmann C, Weiss Y. Return migration: theory and empirical evidence from the US. Br J Indust Relat. 2007:45(2):236-56

Garcia Fernandez J. La Emigración Exterior de España. Madrid: Editorial Ariel; 1965.

Grogger J, Hanson GH. Income maximization and the selection and sorting of international migrants. J Dev Econ. 2011;95:42-57.

Harris JR, Todaro MP. Migration, unemployment and development: a two-sector analysis. Am Econ Rev. 1970;60(5):126-42.

Hatton T, Williamson JG. What fundamentals drive world migration? NBER Working Paper No. 9159; 2002

Instituto Español de Emigración. Panorámica de la Emigración. Editorial Ministerio de Trabajo; 1973

Izquierdo M, Jimeno JF, Lacuesta A. Los Flujos Migratorios de España Durante la Crisis Economic Bulletin Banco de España; 2014

Massey D, Arango J, Hugo G, Kouaouci A, Pellegrino A, Taylor JE. Theories of international migration: a review and appraisal. Popul Dev Rev. 1993;19(3):431-66.

Nadal J. La Población Española (Siglos XVI a XX). Editorial Ariel; 1984

Ortega F, Peri G. The effect of income and immigration policies on international migration, Migration Studies, 1, 1-28; Oxford University Press; 2013

Pedersen PJ, Pytlikova M, Smith N. Selection and network effects? Migration flows into OECD countries 1990-2000. Eur Econ Rev. 2008:52(7):1160-86.

Prados de la Escosura L. Long-run economic growth in Spain since 1800: an international perspective. In: Szirmai E, Van Ark B, Pilat D, editors. Explaining Economic Growth. Amsterdam: North Holland; 1993. p. 285-99.

Zavodny M. Welfare and the locational choices of new immigrants Economic Review - Federal Reserve Bank of Dallas; Second Quarter 1997. 1997.

Submit your manuscript to a SpringerOpen ${ }^{\circ}$ journal and benefit from:

- Convenient online submission

Rigorous peer review

- Immediate publication on acceptance

- Open access: articles freely available online

- High visibility within the field

- Retaining the copyright to your article

Submit your next manuscript at $>$ springeropen.com 